\title{
Natural Radioactivity of Feed Coal and Its by-products in Barapukuria 2×125 MW Coal Fired Thermal Power Plant, Dinajpur, Bangladesh
}

\author{
M. Mehade Hasan ${ }^{1}$, M. I. Ali ${ }^{2}$, D. Paul ${ }^{2}$, M. A. Haydar ${ }^{2}$, S. M. Azharul Islam ${ }^{1}$ \\ ${ }^{I}$ Department of Physics, Jahangirnagar University, Savar, Dhaka, Bangladesh \\ ${ }^{2}$ Health Physics and Radioactive Waste Management Unit (HPWMU), Institute of Nuclear Science and \\ Technology (INST), Atomic Energy Research Establisment (AERE), Bangladesh Atomic Energy Commission, \\ Savar, Dhaka, Bangladesh
}

\begin{abstract}
The detection and measurement of radionuclides in feed coal, bottom ash and fly ash samples collected from Barapukuria $2 \times 125$ MW coal-fired thermal power plant in Dinajpur district of Bangladesh, have been performed by gamma ray spectrometry technique. The average activity concentrations of ${ }^{226} \mathrm{Ra},{ }^{232}$ Th and ${ }^{40} \mathrm{~K}$ in feed coal, bottom ash and fly ash samples were 10.46 $55.24,23.50 \pm 10.88$ and $232.23 \pm 131.94 \mathrm{Bqkg}^{-1}$;

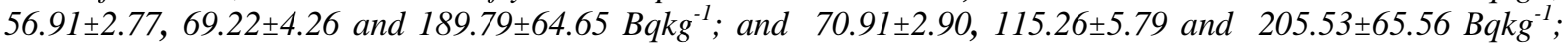
respectively. These measured values were compared with other literature values. The calculated absorbed dose rates were found higher than the worldwide average values for both the bottom ash and fly ash samples. Moreover, the radium equivalent activity in all the samples was less than $370 \mathrm{Bqkg}{ }^{-1}$ and external hazard indices were less than unity (except in FA-1). Therefore, there is no probability of immediate health effect on workers and public due to natural radioactivity present in the samples.
\end{abstract}

Keywords: Natural Radioactivity, Feed Coal, Bottom Ash, Fly Ash, Gamma spectrometry

\section{INTRODUCTION}

The feed coal used in power plants contains various elements organic constituents, inorganic contents such as naturally radioactive potassium, and minerals with inclusion of trace elemental uranium and thorium, each with various physiochemical characteristics in regard to the decay products, their associated half-lives, decay modes, decay energies, leachability etc. About $2.3 \times 10^{9} \mathrm{~kg}$ of this highly caloric form of coal is required in modern plants to produce $1 \mathrm{GW}$ of electrical energy, also yielding of the order of $3 \times 10^{6} \mathrm{~kg}$ ash [1]. Some $40 \%$ of the world energy demand is fulfilled by coal -fired power plant [2].

In various thermal power plants the combustion of coal results in the release of some natural radioactivity which consequently increases the radioactivity in soil,water and atmosphere around thermal power plants. As the radon in the atmosphere, soil, ground water, oil and gas deposits contributes the largest fraction of the natural radiation dose to populations, so tracking its concentration is fundamental for radiation protection, health and hygiene point of view [3]. There has been an increasing demand for electricity generation throughout the world with the ever-increasing growth in human civilization. With the increasing demand for electricity, coal plays an important role in electric power generation worldwide [4]. After the combustion of the coal in the boiler, $20 \%$ of the ash is collected at the bottom of the boiler called bottom ash and $80 \%$ is carried along with flue gases called fly ash. Bottom ash is mixed with water and made into sludge form and sent through pumps into the ash ponds. The ash from this power plant is mainly used in producing cement and other building materials or aggregate in stabilizing roadways [5].

With the advancements in the industrial and technological growth and applications, a general awareness has also arisen regarding the deleterious side effects of the same and has a role to play as lifeline. In some industrial units coal, is used as fuel. The coal combustion in industrial units is associated with the dispersal of radionuclides in the environment. The activities of radionuclides discharged in the atmosphere from coal depend on a number of factors such as activity concentration in coal, ash content in coal, temperature of combustion and efficiency of the filtering systems etc. In the production of electric power, coal is burnt in furnaces operating at temperature upto $1700^{\circ} \mathrm{C}$ and by this process most of the mineral matter in the coal is fused into vitrified ash. A portion of ash and incompletely burnt organic matter drop to the bottom of the furnace as bottom ash or slag. The fly ash, however, is carried through the boiler along with the hot flue gases to the stack where some fractions are collected while the rest escape in to the atmosphere. Thermal Power Stations add to environmental degradation problems through gaseous emissions, particulate matter, fly ash and bottom ash. Ash content being in abundance in Indian coal, problem of fly ash and bottom ash disposal increase day by day. The fly ash generated in thermal power station causes many hazardous diseases like Asthma, Tuberculosis etc. 
The people living within $5 \mathrm{~km}$ radius of coal based power plant suffer from respiratory ailments. Initially, perceptions of objectionable effects of air pollutants were limited to those easily detected like odour, soiling of surfaces and smoke stacks [3]

Bangladesh has a good amount of coal deposit in its territorial area. Especially the northern part of the country is rich in coal deposit. It has five discovered coal mines namely Barapukuria, Phulbari, Khalashpir, Jamalganj and Dighipara and all these mines are located in the northern region of the country. But only the Barapukuria coal mine is currently under production. The coal extracted from these mines is used in various purposes including power generation, burning in the brick fields and so on [6] . The Barapukuria $2 \times 125 \mathrm{MW}$ coal-fired thermal power plant authority is always using the coal extracted from Barapukuria coal mine nearby the plant as feed coal for their power generation system. The system produces two types of coal ash namely bottom ash and fly ash which are being mixed with the environmental elements specially with the sorroundings soil and water.

Moreover, contamination may happen in the surrounding environmental elements such as soil and water and so on due to the leaching of radionuclides due to power generation activity. There is no available data on the radioactivity contents in feed coal, bottom ash and fly ash radiological impact of these samples and power plant on people and environment of Bangladesh. Therefore, this study was designed to conduct a thorough study on the radionuclide contents and radiological implications on the power plant workers, public and environmental elements. Fig. 1 shows the location map of the study area.

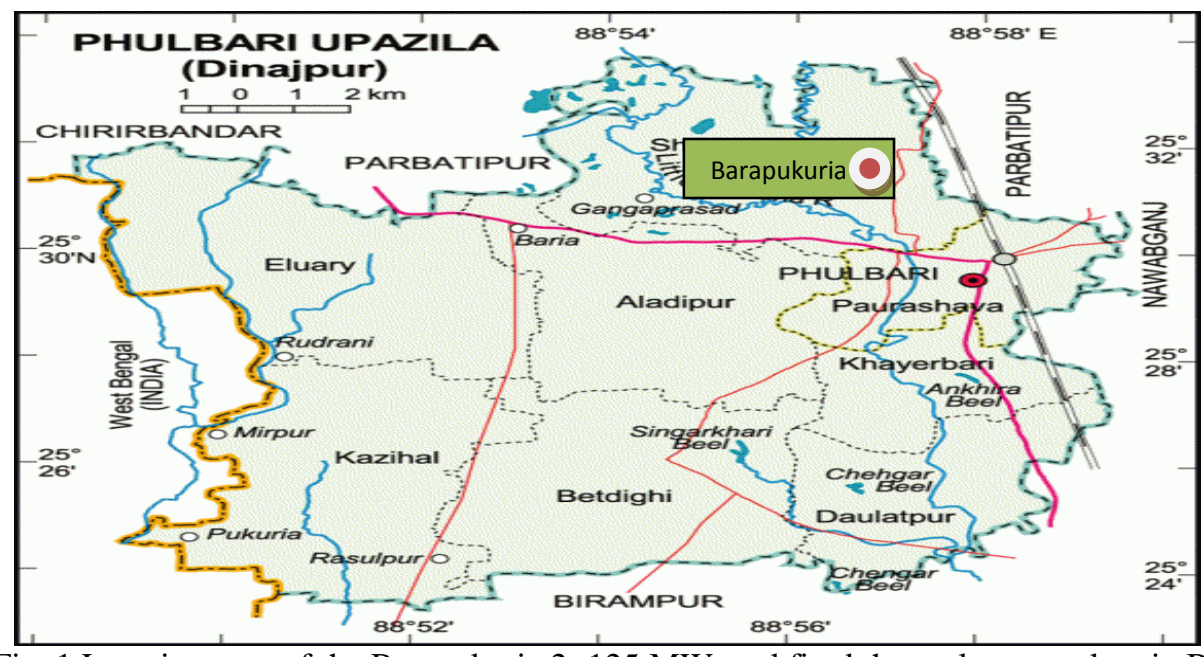

Fig. 1 Location map of the Barapukuria $2 \times 125 \mathrm{MW}$ coal fired thermal power plant in Bangladesh

\subsection{STUDY AREA}

\section{METHODS AND MATERIALS}

Dinajpur is an administrative district under the Rangpur Division and is situated in the Northern part of Bangladesh. Barapukuria power Plant site is located in flat land of the Northwestern "corner" of Bangladesh at about $45 \mathrm{~km}$ east of the district headquarters of Dinajpur, $20 \mathrm{~km}$ east to the border of India. The north-south gauge railway passes through the east part of the site.The site is located about $1 \mathrm{~km}$ north of the coal mine mouth under construction. The only large industrial area nearby is this coal mine including its residential complexes.The nearest town is Phulbari, a Thana (Upazila) headquarter as primary administrative center of the country. Phulbari is located about $6 \mathrm{~km}$ south of the site.

\subsection{SAMPLING LOCATIONS}

A total of 12 samples namely; 4 feed coal and 8 ash samples; were collected from inside of the power plant area. Eight ash samples were divided into two groups namely; bottom ash and fly ash samples. These samples were collected during the whole day on 9 July 2013. Location coordinates of the Barapukuria $2 \times 125$ MW coal fired thermal power plant are latitude $25^{\circ} 33^{\prime} \mathrm{N}$ and longitude $88^{\circ} 57^{\prime} \mathrm{E}$.

\subsection{SAMPLE COLLECTION AND PREPARATION}

It was stated in earlier section that 4 feed coal samples and 8 ash samples were collected from inner area of the power plant .Four feed coal samples were collected from four different coal deposit inside the power plant area. Bottom ash and fly ash samples were collected from four different places and were marked as BA-1, BA-2, BA-3, BA-4 and FA-1, FA-2, FA-3, FA-4, respectively. 


\subsection{SAMPLE PROCESSING}

After the collection of feed coal, bottom ash and fly ash samples, they were transported and preserved at the sample preparation laboratory of the Health Physics and Radioactive Waste Management Unit, Bangladesh Atomic Energy Commission (BAEC), Savar, Dhaka. The samples were then cleaned and dried in the sun and crushed into fine powder by using a grinder except ash samples and collected after passing through $400 \mu \mathrm{m}$ mesh screen. The homogenized samples were then dried in an oven at about $110^{\circ} \mathrm{C}$ for about 24 hours and the weights of the samples were recorded using an electrical balance. The homogenized samples were then transferred to sealable cylindrical plastic containers of $7 \mathrm{~cm}$ height and $5.5 \mathrm{~cm}$ in diameter, marked individually with identification parameters e.g, name and location of the sample, date of preparation and net weight. All the containers are then sealed tightly with an insulating tape around their neck and stored for about 30 days to attain radioactive secular equilibrium between ${ }^{226} \mathrm{Ra}$ and its daughter products.

\subsection{EXPERIMENTAL SET UP}

The detection and measurement of radionuclides in the samples were carried out by gamma spectrometry system using a vertical coaxial cylindrical high purity germanium (HPGe) detector of $172 \mathrm{~cm}^{3}$ active volume and with $40 \%$ relative efficiency. The p-type HPGe detector supplied by CANBERRA (ModelGC4020), had a resolution of $2 \mathrm{keV}$ at $1332 \mathrm{keV}$ of Cobalt-60 gamma-ray line. The detector was coupled to a 16 k-channel analyser. The spectra of all samples were perfectly analysed using Genie-2000 spectra analysis software (which matched various gamma energy peaks to a library of all possible radionuclides) to calculate the concentrations of ${ }^{238} \mathrm{U},{ }^{232} \mathrm{Th}$ and ${ }^{40} \mathrm{~K}$. The detector was enclosed in a cylindrical shielding container made of lead and iron with $11.3 \mathrm{~cm}$ thickness, $51 \mathrm{~cm}$ height and $28 \mathrm{~cm}$ internal diameter and having a fixed bottom and moving cover to reduce the external gamma-ray background. All the samples were counted for $10 \mathrm{ks}$. prior to the measurement of the samples, the environmental gamma background at laboratory site was determined with an identical empty Marinelli beaker and plastic container used in the sample measurement. The energy regions selected for the corresponding radionuclides were $295 \mathrm{keV}$ and $352 \mathrm{keV}$ of ${ }^{214} \mathrm{~Pb}$ and $609 \mathrm{keV}, 1120 \mathrm{keV}$ and $1764 \mathrm{keV}$ for ${ }^{214} \mathrm{Bi}$ and ${ }^{226} \mathrm{Ra}, 583 \mathrm{keV}$ and $2614 \mathrm{keV}$ of ${ }^{208} \mathrm{Tl}, 911 \mathrm{keV}$ and $969 \mathrm{keV}$ of ${ }^{228} \mathrm{Ac}$ for ${ }^{232} \mathrm{Th}$, and $1460 \mathrm{keV}$ for ${ }^{40} \mathrm{~K}[7]$.

\subsection{CALIBRATION OF THE DETECTOR}

In the present study the calibration for the efficiency of the detector was performed by standard source of solid matrices prepared using ${ }^{226} \mathrm{Ra}$ standard solutions. The standard source was prepared using identical container used for the measurement of the samples, e.g., $180 \mathrm{ml}$ plastic container for solid samples. The preparation process of standard sources had been reported elsewhere [8]. The detector efficiency calibration curves as a function of energy for solid matrices are shown in Fig. 2. The energy calibration of the detector was performed by using ${ }^{137} \mathrm{Cs}$ and ${ }^{60} \mathrm{Co}$ point sources.

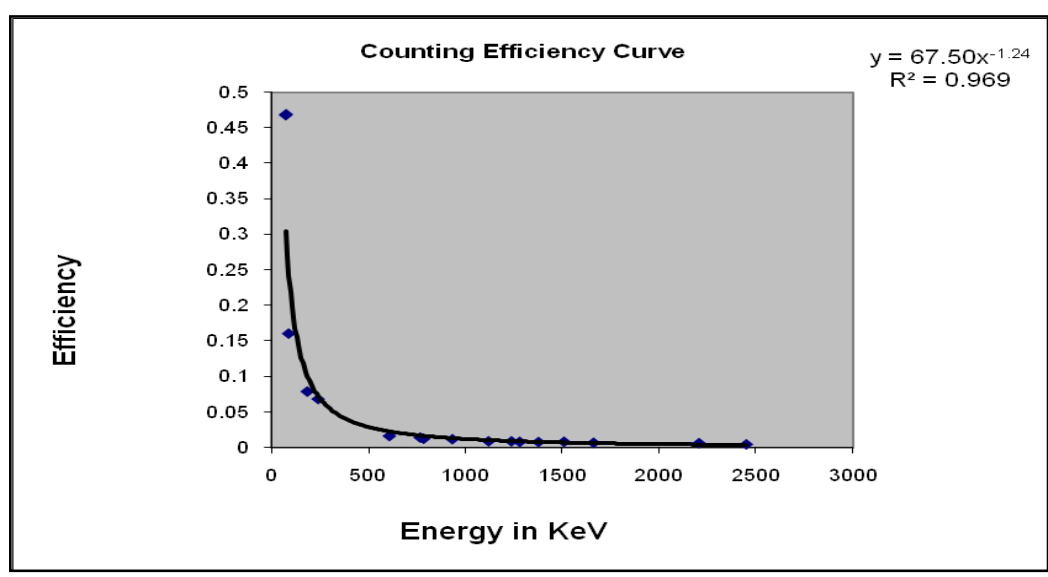

\subsection{THE ACTIVITY CONCENTRATIONS}

\section{THEORETICAL BACKGROUND}

The activity concentrations $(A)$ of each radionuclide in the collected samples were determined by using the following standard equation [9]:

$A=c p s /(E \times I \times W)$

Where, $A=$ Activity concentrations of the sample in $\mathrm{Bqkg}^{-1}$ or $\mathrm{BqL}^{-1}$.

cps $=$ The net counts per second $=\mathrm{cps}$ for the sample $\mathrm{cps}$ for the background value

$E=$ The counting efficiency of the gamma energy

$I=$ Absolute intensity of the gamma ray and 
$W=$ Net weight of the sample (in kilogram or litre).

The uncertainties in the measurements were expressed in terms of standard deviation $( \pm \sigma)$, where $\sigma$ is expressed as [9]:

$\sigma=\left[\frac{N_{s}}{T_{s}^{2}}+\frac{N_{b}}{T_{b}^{2}}\right]^{1 / 2}$

Where, $N_{s}$ is the sample counts measured in time $T_{s}$, and $N_{b}$ is the background counts measured in time $T_{b}$. The standard deviation $\pm \sigma$ in cps was converted into activity in $\mathrm{Bqkg}^{-1}$ according to equation (1).

\subsection{ABSORBED DOSE RATES}

The external outdoor absorbed gamma dose rates due to terrestrial gamma rays from the nuclides ${ }^{226} \mathrm{Ra},{ }^{232} \mathrm{Th}$ and ${ }^{40} \mathrm{~K}$ at $1 \mathrm{~m}$ above the ground level were calculated as [10]:

$D\left(n G y h^{-1}\right)=0.462 A_{R a}+0.604 A_{T h}+0.042 A_{K}$

Where, $A_{R a}, A_{T h}$ and $A_{K}$ are the specific activities of ${ }^{226} \mathrm{Ra},{ }^{232} \mathrm{Th}$ and ${ }^{40} \mathrm{~K}$, respectively in $\mathrm{Bqkg}^{-1}$.

\subsection{OUTDOOR ANNUAL EFFECTIVE DOSE}

The absorbed dose rate was converted into annual effective dose equivalent by using a conversion factor of $0.7 \mathrm{SvGy}^{-1}$ recommended by the UNSCEAR 2000 and 0.2 for the outdoor occupancy factor by considering that the people on the average, spent $20 \%$ of their time in outdoors [11] . The effective dose due to natural activity in the collected samples was calculated by:

$E\left(m\right.$ vvyr $\left.^{-1}\right)=D \times 24 \times 365.25 \times 0.2 \times 0.7 \times 10^{-6}$

\subsection{RADIUM EQUIVALENT ACTIVITY}

In order to assess the health effects from the radioactivity of the earth's surface materials containing ${ }^{238} \mathrm{U},{ }^{232} \mathrm{Th}$ and ${ }^{40} \mathrm{~K}$, the activity of these nuclides is converted into a single quantity termed the radium equivalent $\left(\mathrm{Ra}_{\mathrm{eq}}\right)$. The radium equivalent activity is a weighted sum of activities of ${ }^{226} \mathrm{Ra}$ (daughter of ${ }^{238} \mathrm{U}$ ), ${ }^{232} \mathrm{Th}$ and ${ }^{40} \mathrm{~K}$ based on the assumption that $10 \mathrm{~Bq} \mathrm{~kg}$ of ${ }^{226} \mathrm{Ra}, 7 \mathrm{~Bq} \mathrm{~kg}^{-1}$ of ${ }^{232} \mathrm{Th}$ and $130 \mathrm{~Bq} \mathrm{~kg}^{-1}$ of ${ }^{40} \mathrm{~K}$ produce the same gamma-ray dose rates. It is calculated by using the following relation [12] :

$R a_{e q}\left(B q k g^{-1}\right)=A_{R a}+1.43 A_{T h}+0.077 A_{K}$

Where, $A_{R a}, A_{T h}$ and $A_{K}$ are the specific activities of ${ }^{226} \mathrm{Ra},{ }^{232} \mathrm{Th}$ and ${ }^{40} \mathrm{~K}$, respectively in $\mathrm{Bqkg}^{-1}$.

\subsection{EXTERNAL HAZARD INDEX}

The external hazard index $\left(\mathrm{H}_{\mathrm{ex}}\right)$ is the indoor radiation dose rate due to the external exposure to gamma radiation in construction materials of dwelling which was calculated by [13].

$$
\boldsymbol{H}_{e x}=\frac{\boldsymbol{A}_{R a}}{370}+\frac{\boldsymbol{A}_{T h}}{259}+\frac{\boldsymbol{A}_{K}}{4810}
$$

Where, $A_{R a}, A_{T h}$ and $A_{K}$ have the same meanings as in equation (3), and (5).

\section{RESULTS AND DisCUSSIONS}

The results of the present study on the two types of samples are summarized in following sections.

\subsection{ACTIVITY CONCENTRATION IN FEED COAL SAMPLES}

Activity concentrations of ${ }^{226} \mathrm{Ra},{ }^{232} \mathrm{Th}$ and ${ }^{40} \mathrm{~K}$ in feed coal samples were determined by equation (1) and the results for the same are shown in Table 1 with the uncertainty level of $\pm \sigma$. The results for the radionuclides $\left({ }^{226} \mathrm{Ra},{ }^{232} \mathrm{Th}\right.$ and $\left.{ }^{40} \mathrm{~K}\right)$ are shown independently in Fig. 3, Fig. 4 and Fig. 5, respectively.

In feed coal samples, The activity concentrations of ${ }^{226} \mathrm{Ra},{ }^{232} \mathrm{Th}$ and ${ }^{40} \mathrm{~K}$ were found to be in the range of $6.18 \pm 4.20$ to $13.84 \pm 6.18 \mathrm{Bqkg}^{-1}$ with an average value of $10.46 \pm 5.24 \mathrm{Bqkg}^{-1}$; $17.11 \pm 10.29$ to $31.10 \pm 10.18 \mathrm{Bqkg}^{-1}$, with an average value of $23.50 \pm 10.88 \mathrm{Bqkg}^{-1}$ and $147.02 \pm 112.65$ to $390.18 \pm 160.95 \mathrm{Bqkg}^{-1}$, with an average value of $232.23 \pm 131.94 \mathrm{Bqkg}^{-1}$ respectively. All the values were lower than the worldwide average values of 35,30 and $400 \mathrm{Bqkg}^{-1}$ successively [10].

\subsection{ACTIVITY CONCENTRATION IN BOTTOM ASH SAMPLES}

Activity concentrations of ${ }^{226} \mathrm{Ra},{ }^{232} \mathrm{Th}$ and ${ }^{40} \mathrm{~K}$ in bottom ash samples were determined by equation

(1) and the results for the same are shown in Table 2 with the uncertainty level of $\pm \sigma$.

In bottom ash samples, the activity concentrations of ${ }^{226} \mathrm{Ra},{ }^{232} \mathrm{Th}$ and ${ }^{40} \mathrm{~K}$ were found to be in the range of $39.22 \pm 2.64$ to $72.88 \pm 2.83 \mathrm{Bqkg}^{-1}$, with an average value of $56.91 \pm 2.77 \mathrm{Bqkg}^{-1} ; 51.86 \pm 8.35$ to $88.73 \pm 2.93 \mathrm{Bqkg}^{-}$ ${ }^{1}$, with an average value of $69.22 \pm 4.26 \mathrm{Bqkg}^{-1}$ and $183.04 \pm 64.18$ to $197.23 \pm 63.47 \mathrm{Bqkg}^{-1}$, with an average value of $189.79 \pm 64.65 \mathrm{Bqkg}^{-1}$ respectively which all were higher than the worldwide average value of 35,30 and 400 $\mathrm{Bqkg}^{-1}$ except ${ }^{40} \mathrm{~K}$ successively [10]. 


\subsection{ACTIVITY CONCENTRATION IN FLY ASH SAMPLE}

Activity concentrations of ${ }^{226} \mathrm{Ra},{ }^{232} \mathrm{Th}$ and ${ }^{40} \mathrm{~K}$ in fly ash samples were determined by equation (1) and the results for the same are shown in Table 3 with the uncertainty level of $\pm \sigma$.

In fly ash samples, the activity concentrations of ${ }^{226} \mathrm{Ra},{ }^{232} \mathrm{Th}$ and ${ }^{40} \mathrm{~K}$ were found in the range of $22.63 \pm 0.69$ to $107.69 \pm .03 \mathrm{Bqkg}^{-1}$, with an average value of $70.91 \pm 2.90 \mathrm{Bqkg}^{-1} ; 30.04 \pm 0.74$ to $176.97 \pm 8.75 \mathrm{Bqkg}^{-1}$, with an average value of $115.26 \pm 5.79 \mathrm{Bqkg}^{-1} ; 25.14 \pm 8.81$ to $400.19 \pm 79.25 \mathrm{Bqkg}^{-1}$, with an average value of $205.525 \pm 65.56 \mathrm{Bqkg}^{-1}$ respectively. All the values were significantly higher than the worldwide average value of 35,30 and $400 \mathrm{Bqkg}^{-1}$ except ${ }^{40} \mathrm{~K}$ respectively [10] .

\subsection{RADIOLOGICAL INDICES}

In order to assess the health effects, the radiation hazards such as absorbed dose rate (D), outdoor annual effective dose (E), radium equivalent activity $\left(\mathrm{Ra}_{\mathrm{eq}}\right)$ and external hazard index $\left(\mathrm{H}_{\mathrm{ex}}\right)$ have been calculated from the activity concentrations of ${ }^{226} \mathrm{Ra},{ }^{232} \mathrm{Th}$ and ${ }^{40} \mathrm{~K}$ using the equations (3), (4), (5) and (6), respectively and the values are shown in Table 4.

From Table 4, it is seen that absorbed dose rate due to the terrestrial gamma rays at $1 \mathrm{~m}$ above the ground were in the range of 21.66 to $34.62 \mathrm{nGyh}^{-1}$ with an average $26.34 \mathrm{nGyh}^{-1}$ for feed coal samples and those for bottom ash samples were 57.13 to $95.55 \mathrm{nGyh}^{-1}$ with an average value of $76.07 \mathrm{nGyh}^{-1}$, and for fly ash samples were 29.65 to 162.49 with an average value of $111.01 \mathrm{nGyh}^{-1}$ respectively. These values were higher than the world average value of $55 \mathrm{nGyh}^{-1}$ in both the ash samples except in feed coal samples [10].

The outdoor annual effective dose for feed coal samples ranged from 0.03 to $0.4 \mathrm{mSvyr}^{-1}$ with an average value of $0.0325 \mathrm{mSvyr}^{-1}$. The outdoor annual effective dose was 0.07 to $0.12 \mathrm{mSvyr}^{-1}$ with an average $0.095 \mathrm{mSvyr}^{-1}$ for bottom ash samples and 0.04 to $0.20 \mathrm{mSvyr}^{-1}$ with an average value of $0.14 \mathrm{mSvyr}^{-1}$ for fly ash samples; which were less than the world average value of $0.460 \mathrm{mSvyr}^{-1}[10]$.

The mean value of radium equivalent activity was $44.26 \mathrm{Bqkg}^{-1}$ for feed coal samples, $170.38 \mathrm{Bqkg}^{-1}$ for bottom ash samples, and $151.37 \mathrm{Bqkg}^{-1}$ for fly ash samples. However, all the values obtained here for radium equivalent activity fall far below the limit of $370 \mathrm{Bqkg}^{-1}[10]$.The mean value of external radiation hazard index was 0.16 for feed coal samples, 0.46 for bottom ash and 0.68 for fly ahs samples which all were comparable to the unity indicating the non-hazardous category of the samples. The values of hazard indices confirmed that it was safe to carry out the activities in the area for the power plant workers, general people and there were no yet significant radiological impact of coal mining on the environment. But the sample code FA-1 shows the value of external radiation hazard index is unit so it is not safe for the environmental elements as well as power plant workers and general people.

Table 1: Activity Concentration in $\left(\mathrm{Bqkg}^{-1}\right)$ in Different Feed Coal Samples

\begin{tabular}{|c|c|c|c|}
\hline Sample Code & ${ }^{226} \mathrm{Ra}$ & ${ }^{232} \mathrm{Th}$ & ${ }^{40} \mathrm{~K}$ \\
\hline FC-1 & $11.79 \pm 5.99$ & $21.17 \pm 13.47$ & $390.18 \pm 160.95$ \\
\hline FC-2 & $13.84 \pm 6.18$ & $31.10 \pm 10.18$ & ND \\
\hline FC-3 & $6.18 \pm 4.20$ & $24.62 \pm 9.56$ & $147.02 \pm 112.65$ \\
\hline FC-4 & $10.01 \pm 4.58$ & $17.11 \pm 10.29$ & $159 . .50 \pm 122.22$ \\
\hline Average & $10.46 \pm 5.24$ & $23.50 \pm 10.88$ & $232.23 \pm 131.94$ \\
\hline World Average [10] & 35 & 30 & 400 \\
\hline
\end{tabular}

\section{ND= Not Detected}

Table 2: Activity Concentration in $\left(\mathrm{Bqkg}^{-1}\right)$ in Different Bottom Ash Samples

\begin{tabular}{|c|c|c|c|}
\hline Sample Code & ${ }^{226} \mathrm{Ra}$ & ${ }^{232} \mathrm{Th}$ & ${ }^{40} \mathrm{~K}$ \\
\hline BA-1 & $62.70 \pm 2.90$ & $69.14 \pm 2.95$ & $191.32 \pm 67.09$ \\
\hline BA-2 & $72.88 \pm 2.83$ & $88.73 \pm 2.93$ & $197.23 \pm 63.47$ \\
\hline BA-3 & $52.82 \pm 2.72$ & $67.13 \pm 2.82$ & $187.55 \pm 63.85$ \\
\hline BA-4 & $39.22 \pm 2.64$ & $51.86 \pm 8.25$ & $183.04 \pm 64.18$ \\
\hline Average & $56.91 \pm 2.77$ & $69.22 \pm 4.26$ & $189.79 \pm 64.65$ \\
\hline World Average [10] & 35 & 30 & 400 \\
\hline
\end{tabular}

Table 3: Activity Concentration in $\left(\mathrm{Bqkg}^{-1}\right)$ in Different Fly Ash Samples

\begin{tabular}{|c|c|c|c|}
\hline Sample Code & ${ }^{226} \mathrm{Ra}$ & ${ }^{232} \mathrm{Th}$ & ${ }^{40} \mathrm{~K}$ \\
\hline FA-1 & $107.69 \pm 4.03$ & $176.97 \pm 8.75$ & $139.17 \pm 88.96$ \\
\hline FA-2 & $66.93 \pm 3.60$ & $136.60 \pm 8.10$ & $407.60 \pm 85.23$ \\
\hline FA-3 & $86.37 \pm 3.25$ & $117.41 \pm 5.57$ & $25.19 \pm 79.25$ \\
\hline FA-4 & $22.63 \pm 0.69$ & $30.04 \pm 0.74$ & $205.52 \pm 65.56$ \\
\hline Average & $70.91 \pm 2.90$ & $115.26 \pm 5.79$ & 400 \\
\hline World Average [10] & 35 & 30 & \\
\hline
\end{tabular}


Natural Radioactivity of Feed Coal and Its by-products in Barapukuria 2×125 MW Coal Fired

Table 4: Absorbed dose rate (D), outdoor annual effective dose (E), radium equivalent activity $\left(\mathrm{R}_{\mathrm{eq}}\right)$ and external hazard index of all feed coal, bottom ash and fly ash samples.

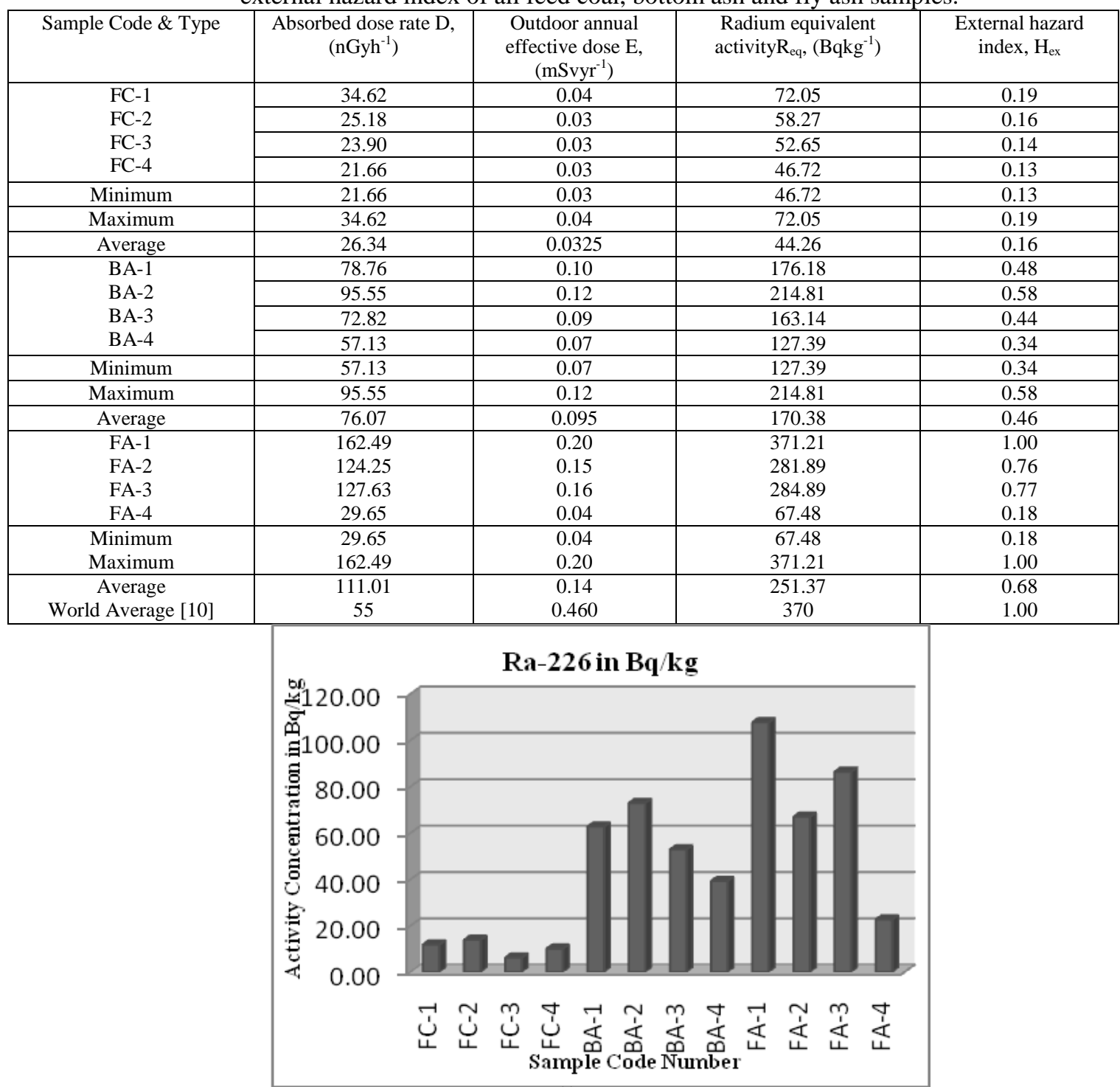

Fig. 3 Distribution of ${ }^{226} \mathrm{Ra}$ in all collected samples

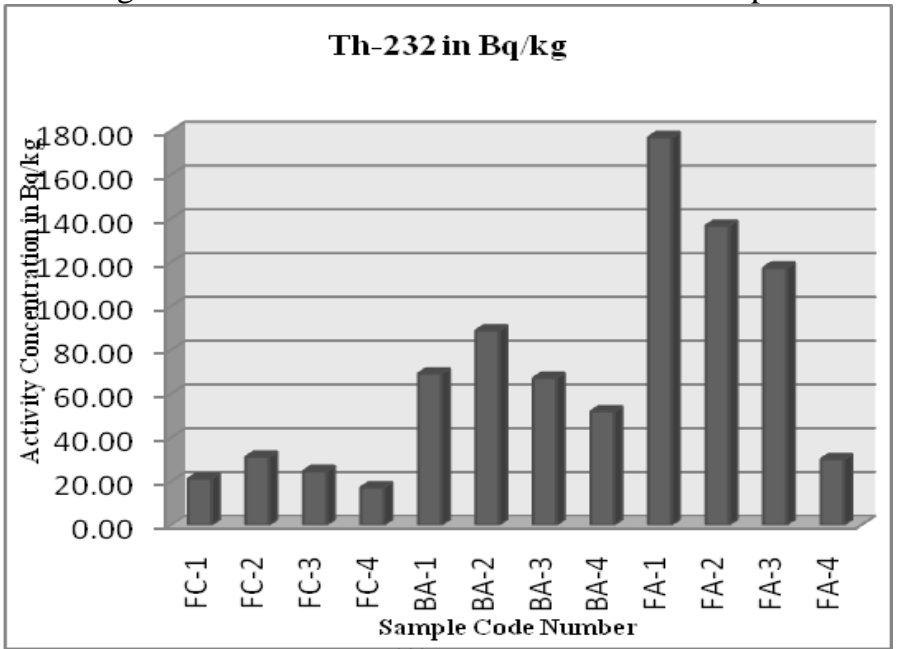

Fig. 4 Distribution of ${ }^{232}$ Th in all collected samples 


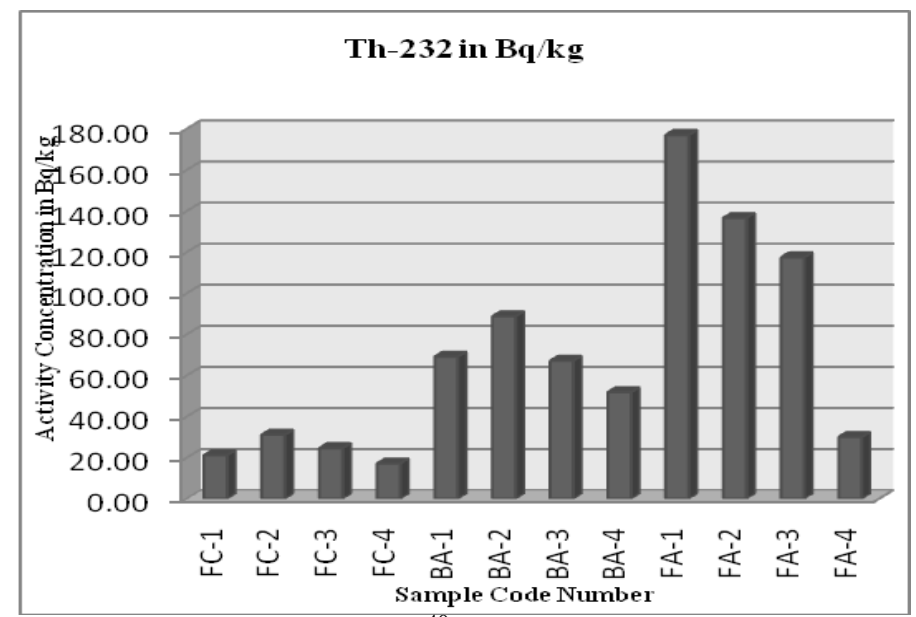

Fig. 5 Distribution of ${ }^{40} \mathrm{~K}$ in all collected samples

\section{CONCLUSION}

The radionuclide contents, activity concentrations and radiological impact of the feed coal, bottom ash and fly ash samples collected from the Barapukuria coal fired thermal power plant in Dinajpur district of Bangladesh and its adjacent areas were investigated in the present study. The results indicated that only the natural radionuclides were present in the samples. The radioactivity concentrations of ${ }^{226} \mathrm{Ra},{ }^{232} \mathrm{Th}$ and ${ }^{40} \mathrm{~K}$ were relatively higher than the world average values except in feed coal samples. The calculated average absorbed dose rates were found higher than the worldwide average values for both the bottom ash and fly ash samples. The radium equivalent activity $\left(\mathrm{R}_{\mathrm{eq}}\right)$ in all the samples were less than the world average value and the obtained external hazard $\left(\mathrm{H}_{\mathrm{ex}}\right)$ indices were far below the unity (except in FA-1). The lower values of radiological indices indicated that there is no probability of immediate health effect on workers and public due to natural radioactivity present in the samples. The environment under current study adjacent to the power plant area is somewhat contaminated for fly ash due to the power plant activities [6].

\section{Acknowledgements}

The authors are thankful to Barapukuria $2 \times 125 \mathrm{MW}$ coal fired thermal power plant Authority for giving the permission to collect the samples, specially Mr. Dinesh Chandra Mistry, Executive Engineer (coal \& ash) for his kind help to collect the samples. The authors also like to thank the technical support staffs of HPRWMU for their help in conducting the study.

\section{REFERENCES}

[1] Beck, H. L., Miller, K. M., 1980. Some radiological aspects of coal combustion. IEE Trans. Nucl. Sci.27, 689-694.

[2] International energy outlook (IEO). Report Number: DOE/EIA-0484 (2011), Release Date: September 19, 2011,available at (http://www.eia.gov/forecasts/ieo/index.cfm)

[3] A. K. Garg, R. P. Chauhan, EraGarg, Shikha Garg, Measurement of alpha radioactive air pollutants in some coal fired industrial units of northern India, American International Journal of Research in Science, Technology, Engineering \& Mathematics, ISSN (Print): 2328-3491, ISSN (Online): 2328-3580, ISSN (CD-ROM): 2328-3629, Available online at http://www.iasir.net.

[4] Xinwei Lu, Xiaodan Jia and Fengling Wang, Natural radioactivity of coal and its by-products in the Baoji coal-fired power plant, China, CURRENT SCIENCE, 1508 VOL. 91, NO. 11, 10 DECEMBER 2006.

[5] Sahithi Avirneni, Dharmateja Bandlamudi, Environmental Impact of Thermal Power Plant in India and Its Mitigation Measure, International Journal of Modern Engineering Research (IJMER) Vol.3, Issue.2, March-April. 2013, pp-1026-1031, www. ijmer.com.

[6] M. Mehade Hasan, M. I. Ali, D. Paul, M. A. Haydar, S. M. A. Islam, Measurement of Natural Radioactivity in Coal, Soil and Water Samples Collected from Barapukuria Coal Mine in Dinajpur District of Bangladesh, Journal of Nuclear and Particle Physics, USA, vol.3, No. 4, pp. 63-71(2013).

[7] C. E. Roessier, Z.A. Smith, W.E. Bloch and R.J Prince, Uranium and radium in Floride phosphate materials, Health Phys. vol. 37, 1970, pp. 269-277.

[8] G. F. Knoll, Radiation Detection and Measurement, Third edn.1998, New York.

[9] M. A. Usif and A. E. Taher, Radiological assessment of Abu-Tartur phosphate, western desert Egypt, Radiation Protection Dosimetry, vol.130, 2008, pp. 228-235.

[10] UNSCEAR, Sources and effects of ionizing radiation, Report of the United Nations Scientific Committee on the Effects of Atomic Radiation to the General Assembly, (United Nations, New York, USA,2000), Annex.

[11] K. Debertin and R.G. Helmer, Gammand X-ray spectrometry detectors, North Holland, 1988.

[12] Beretka, J. and Mathew, P. J. , Natural radioactivity of Australian buildings, materials, industrial wastes and by products, Health Physic, 48, 87-95 (1985).

[13] Lu, X. And Xiolan, Z., Measurement of natural radioactivity in sand samples collected from the Booje Weithe sand park, China, Environ. Geol. 50, 977-988 (2006). 